\title{
Influence of Poultry Litter and Poultry Litter Biochar on Soil Microbial Respiration and Nitrifying Bacteria Activity
}

\author{
M. Mierzwa-Hersztek ${ }^{1}$ - A. Klimkowicz-Pawlas ${ }^{2}$ - K. Gondek ${ }^{1}$
}

Received: 8 March 2017 / Accepted: 5 July 2017 / Published online: 12 July 2017

(C) The Author(s) 2017. This article is an open access publication

\begin{abstract}
The application of organic materials, such as poultry litter or poultry litter biochar, may lead to major changes in the structural and functional diversity of microbial populations. The understanding of the relationship between microorganisms and environment is crucial to assess the effect of organic materials on soil. Therefore, the objective was to evaluate the influence of the addition of poultry litter ( $5 \mathrm{t} \mathrm{DM} \mathrm{ha}^{-1}$ ) and poultry litter biochar in doses of $2.25 \mathrm{t}$ and $5 \mathrm{t} \mathrm{DM} \mathrm{ha}{ }^{-1}$ on soil respiration activity, microbial biomass, and nitrifying bacteria activity. In soils with poultry litter biochar added in $2.25 \mathrm{t}$ and $5 \mathrm{t} \mathrm{DM} \mathrm{ha} \mathrm{Da}^{-1}$ doses, microbial biomass was significantly higher than in
\end{abstract}

treatment with mineral fertilisation applied (MF), by 59 and $77 \%$, respectively. The significantly highest basal respiration value was determined in soil with $5 \mathrm{t} \mathrm{DM} \mathrm{ha}^{-1}$ biochar. The application of poultry litter had significant effect on nitrifying bacteria activity (increase by 50\%). Poultry litter biochar added to the soil in both doses contributed to an increase in nitrifying bacteria activity by 36 and $34 \%$, respectively compared to MF treatment. Biochar had more adverse effect on soil microbial biomass and nitrifying bacteria activity than non-converted poultry litter, but it had significant effect on soil respiration activity.

M. Mierzwa-Hersztek

monika6_mierzwa@wp.pl; m.mierzwa@ur.krakow.pl

1 Department of Agricultural and Environmental Chemistry, University of Agriculture in Krakow, Al. Mickiewicza 21, 31-120 Krakow, Poland

2 Department of Soil Science Erosion and Land Protection, Institute of Soil Science and Plant Cultivation-State Research Institute, Czartoryskich 8, 24-100 Pulawy, Poland 


\section{Graphical Abstract}

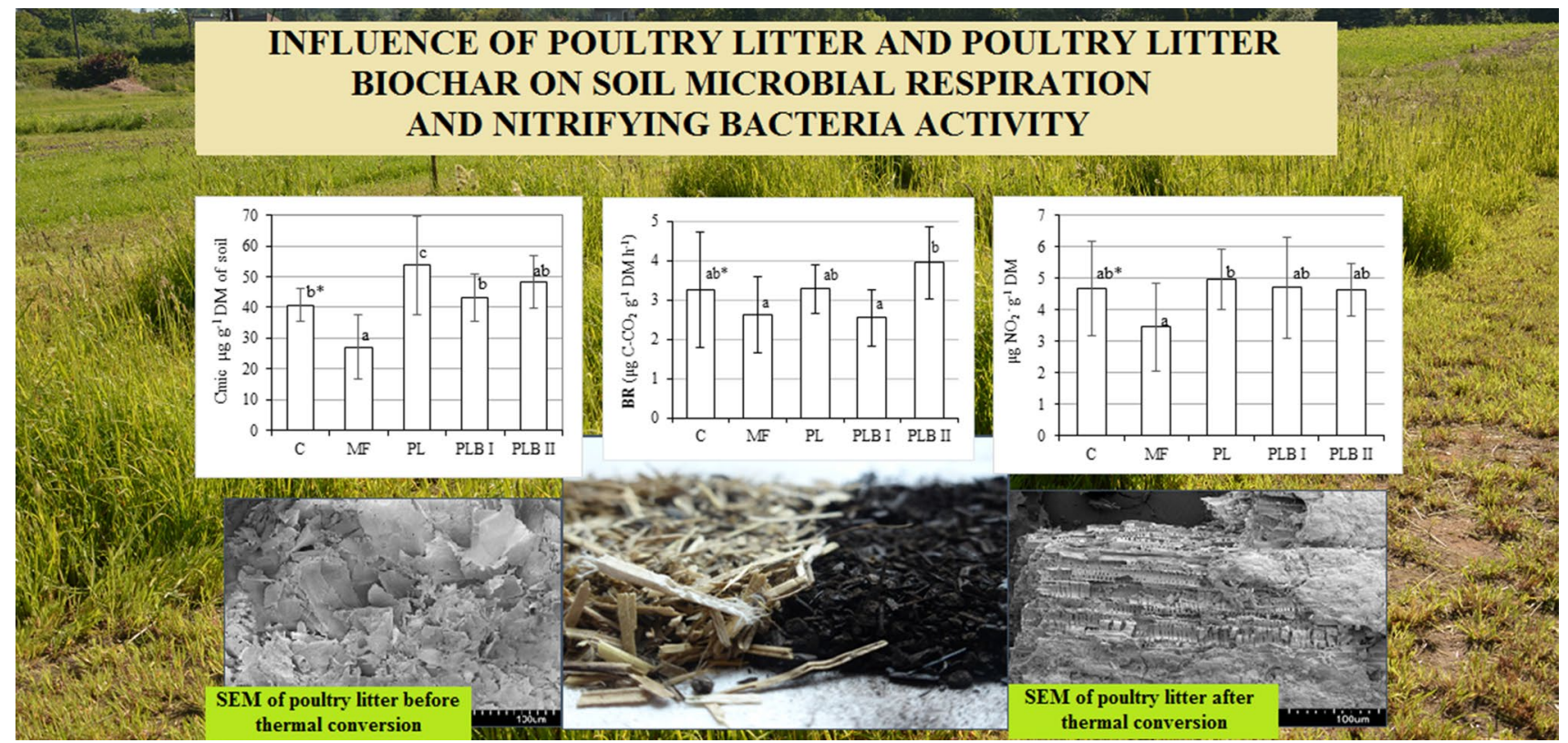

Keywords Biochar S Soil - Poultry litter - Microbial biomass $\cdot$ Microbial respiration $\cdot$ Nitrifying bacteria activity

\section{Introduction}

The effect of human agricultural and non-agricultural activity on soils is assessed mainly by determining the chemical properties of soil. However, this assessment should be supported by the analysis of biological parameters or by the application of bioindication methods [21], as they are much more sensitive to changes of environmental conditions compared to soil chemical and physical indicators. Additionally, biological indicators are considered to be more complex and difficult to interpret. Many authors underlined the importance of determining biological indicators of soil in order to comprehensively identify and assess present and future changes in soil. It is especially crucial if a solid product of thermal conversion of biomass, i.e. biochar, is applied to soil [2, 34, 47].

According to some authors, microorganisms play a key role in the transformation of biochar in soil [20,34, 40]. It was shown that biochar applied to the soil increases the activity of soil microorganisms and activates dormant microorganisms. This, in turn, leads to an increase in soil respiration activity [46] which may result from biotic consumption of nutrients introduced with an organic material [55], abiotic sorption of $\mathrm{CO}_{2}$, or interaction between biochar and soil organic matter [37]. As stated by Steinbeiss et al. [36, 48], biochar applied to the soil may create perfect habitat for microorganisms, because the high surface area and porosity of biochar enable it to adsorb or retain nutrients and water.

Qualitative changes in microbial populations have a significant impact on the functional integrity of soil, whereas the microbial diversity of soil is fundamental for sustainable management of the natural environment. Soil microorganisms play a key role in many processes which are essential for the environment as well as ecological functions of soil [47]. The appropriate condition of groups of soil microorganisms and, therefore, their adequate quantity, activity and diversity, are a prerequisite for the proper functioning of terrestrial ecosystems [3, 47].

The application of organic materials, such as poultry litter or poultry litter biochar, may lead to major changes in the structural and functional diversity of microbial populations $[1,2,34,36]$. Undoubtedly, this is due to the potential of microorganisms to react quickly to the introduction into their habitat of substances with different physical and chemical properties. Kuzyakov et al. [34] and Keith et al. [32] indicated that the application of biochar to soil results in the so-called 'co-metabolic' (or 'co-oxidation') decomposition, which is the microbial response to the introduction of an additional source of $\mathrm{C}$ into the soil.

The term 'co-metabolic' describes the process in which microorganisms oxidise organic substances without being able to utilise the energy derived from oxidation to support microbial growth. Other materials may be more resistant to soil microorganisms as well as be more stable and durable [39]. This is why soil microorganisms are a sensitive and early indicator of the state of soil environment and toxic 
substances present therein [41, 43]. High spatial and temporal variability of microbial parameters results from the sensitivity of microorganisms to soil contamination. Therefore, it is necessary to simultaneously assess both the biomass and respiration activity of microorganisms, as well as chemical properties of soil.

Measurements of respiration activity (basal respiration), microbial biomass, and soil nitrifying activity are one of the most frequently conducted microbiological analyses of soil. They are sensitive indicators to monitor biochemical processes in soil [47, 50]. Most studies published so far recognised the importance of soil microorganisms in the conversion and storage of carbon, as well as in the maximisation of the potential benefits of biochar applied to the soil to stimulate its biological activity and increase the retention of nutrients introduced with fertilisers [4, 24]. However, these studies lack information on the biochar's effect on soil respiration activity and, above all, nitrifying bacteria activity, which are one of the most sensitive indicators of changes in the soil environment. Since soil microorganisms are crucial for ecosystems, studies on their activity after the application of biochar are of great scientific importance and under constant discussion.

The understanding of the relationship between microorganisms and environment is crucial to assess the effect of organic materials on soil. Therefore, the objective of this study was to evaluate the influence of the addition of poultry litter and poultry litter biochar on the selected biological properties of soil, such as: soil respiration activity, microbial biomass, and nitrifying bacteria activity.

\section{Materials and Methods}

\section{Preparation of Poultry Litter and Poultry Litter Biochar}

The biochar used in the experiment was produced from poultry litter and adequately prepared as poultry litter (dried at $70^{\circ} \mathrm{C}, 4 \mathrm{~mm}$ ground in the laboratory mill). Thermal conversion was carried out using a station for gasification of biomass, under a limited supply of air (1-2\%) [22]. The rate of heating the combustion chamber was $10{ }^{\circ} \mathrm{C} \mathrm{min}^{-1}$. Temperature in the combustion chamber was $300^{\circ} \mathrm{C}$, and exposure time was $15 \mathrm{~min}$. The pyrolysis time and temperature were established on the basis of own preliminary examinations and results reported in the literature $[1,17]$.

In order to identify the chemical composition of poultry litter before and after thermal conversion, dry matter content was determined after drying the materials at $105^{\circ} \mathrm{C}$ for $12 \mathrm{~h}$ [30] (Table 1). Subsequently, the materials were ground in the laboratory mill and subjected to chemical analyses.

The contents of total carbon, nitrogen and sulphur were determined on the CNS analyser (Vario MAX Cube, Elementar) [15]. The total contents of macroelements and trace elements were determined after incineration of the sample in a chamber furnace (at $450^{\circ} \mathrm{C}$ for $12 \mathrm{~h}$ ) and mineralisation of the residue in a mixture of concentrated nitric and perchloric acids (3:2) (v/v) by inductively coupled plasma optical emission spectroscopy (ICP-OES) using the Perkin Elmer Optima 7300 DV instrument [42].

Specific surface area $\left(\mathrm{S}_{\mathrm{BET}}\right)$ of organic materials, as well as pore volume and diameter were determined using the multifunction accelerated surface area and porosimetry analyser ASAP 2010 (Micromeritics, the USA). Specific surface area was determined by physical adsorption of nitrogen at liquid nitrogen temperature $\left(77^{\circ} \mathrm{K}\right)$ from the Brunauer-Emmet-Teller equation. Before measuring specific surface area, the studied samples were subjected to desorption at $105^{\circ} \mathrm{C}$ in vacuum and rinsed with pure helium. Sample degassing time was $16 \mathrm{~h}$. The surface degassing state was controlled in automatic mode [6]. Selected chemical properties of organic materials used in the experiment are shown in Table 1.

\section{Micro-Plot Experiment Design and Soil Sampling}

Micro-plot tests were conducted in April 2014 on arable land located in southern Poland $\left(50^{\circ} 08.404^{\prime} \mathrm{N}\right.$; $\left.19^{\circ} 85.362^{\prime} \mathrm{E}\right)$. The soil from the tested area was classified as typical Eutric Cambisols with the granulometric composition of loamy sand (FAO World reference base for soil resources [53]. The experiment had a completely randomized block design (a latin square) with three replications that had the following treatments: $\mathrm{C}$-control soil (non-fertilised); $\mathrm{MF}$-soil + NPK fertilisers; $\mathrm{PL}-\mathrm{soil}+\mathrm{NPK}+5 \mathrm{t} \mathrm{DM} \mathrm{ha}^{-1}$ of poultry litter; PLB Isoil $+\mathrm{NPK}+2.25 \mathrm{t} \mathrm{DM} \mathrm{ha}^{-1}$ of poultry litter-derived biochar and PLB II-soil + NPK + $5 \mathrm{t} \mathrm{DM} \mathrm{ha}^{-1}$ of poultry litter-derived biochar (PLB II). The area of one plot was $1 \mathrm{~m}^{2}$. To create comparable conditions, the following doses of mineral fertilisers were added: $100 \mathrm{~kg} \mathrm{~N}^{-1}, 40 \mathrm{~kg} \mathrm{P} \mathrm{ha}^{-1}$ and $120 \mathrm{~kg} \mathrm{~K} \mathrm{ha}^{-1}$. The dose of phosphorus was applied once under first crop in the form of enriched triple superphosphate. Potassium was introduced in the form of potassium salt, and nitrogen in the form of ammonium nitrate. Assuming that three crops are to be harvested, doses of potassium and nitrogen were divided into three equal parts. The poultry litter was mixed, before and after thermal conversion, with the topsoil $(0-10 \mathrm{~cm})$, and then a pasture grass mix was sown using $60 \mathrm{~kg} \mathrm{ha}^{-1}$ of seeds.

After the end of the growing season, soil samples were collected from each plot from the $0-10 \mathrm{~cm}$ soil layer using 
Table 1 Selected properties of poultry litter and biochar produced from this material and used for a field experiment to assess its effect on soil microbial parameters

\begin{tabular}{|c|c|c|c|}
\hline Determination & Unit & Poultry litter (PL) & $\begin{array}{l}\text { Poultry litter } \\
\text { biochar (PLB) }\end{array}$ \\
\hline $\mathrm{pH} \mathrm{H}_{2} \mathrm{O}$ & - & $7.53 \pm 0.02$ & $8.10 \pm 0.02$ \\
\hline Electrical conductivity (EC) & $\mu \mathrm{S} \mathrm{cm}^{-1}$ & $49.1 \pm 12.4$ & $91.5 \pm 2.60$ \\
\hline Dry matter & $\mathrm{g} \mathrm{kg}^{-1}$ & $445 \pm 1$ & $986 \pm 0$ \\
\hline Ash & $\mathrm{g} \mathrm{kg}^{-1} \mathrm{DM}$ & $312.6 \pm 0.66$ & $420.5 \pm 0.43$ \\
\hline $\mathrm{C}_{\text {total }}$ & $\mathrm{g} \mathrm{kg}^{-1} \mathrm{DM}$ & $323 \pm 0.30$ & $377 \pm 0.30$ \\
\hline Dissolved organic carbon (DOC) & $\mathrm{g} \mathrm{kg}^{-1} \mathrm{DM}$ & $13.9 \pm 0.21$ & $9.15 \pm 0.01$ \\
\hline $\mathrm{N}_{\text {total }}$ & $\mathrm{g} \mathrm{kg}^{-1} \mathrm{DM}$ & $24.9 \pm 0.74$ & $26.2 \pm 1.10$ \\
\hline Organic nitrogen & $\mathrm{g} \mathrm{kg}^{-1} \mathrm{DM}$ & $23.2 \pm 0.21$ & - \\
\hline $\mathrm{N}-\mathrm{NH}_{4}$ & $\mathrm{~g} \mathrm{~kg}^{-1} \mathrm{DM}$ & $1.44 \pm 0.08$ & - \\
\hline $\mathrm{S}_{\text {total }}$ & $\mathrm{g} \mathrm{kg}^{-1} \mathrm{DM}$ & $0.16 \pm 0.02$ & $0.18 \pm 0.02$ \\
\hline $\mathrm{P}_{\text {total }}$ & $\mathrm{g} \mathrm{kg}^{-1} \mathrm{DM}$ & $18.3 \pm 2.20$ & $27.6 \pm 2.90$ \\
\hline $\mathrm{K}_{\text {total }}$ & $\mathrm{g} \mathrm{kg}^{-1} \mathrm{DM}$ & $29.9 \pm 0.66$ & $36.7 \pm 1.81$ \\
\hline $\mathrm{Cd}_{\text {total }}$ & $\mathrm{mg} \mathrm{kg}^{-1} \mathrm{DM}$ & $0.37 \pm 0.01$ & $0.54 \pm 0.07$ \\
\hline $\mathrm{Cr}_{\text {total }}$ & $\mathrm{mg} \mathrm{kg}^{-1} \mathrm{DM}$ & $12.4 \pm 0.33$ & $15.8 \pm 1.68$ \\
\hline $\mathrm{Ni}_{\text {total }}$ & $\mathrm{mg} \mathrm{kg}^{-1} \mathrm{DM}$ & $8.24 \pm 0.41$ & $11.6 \pm 0.93$ \\
\hline $\mathrm{Cu}_{\text {total }}$ & $\mathrm{mg} \mathrm{kg}^{-1} \mathrm{DM}$ & $42.0 \pm 1.50$ & $64.5 \pm 7.80$ \\
\hline $\mathrm{Pb}_{\text {total }}$ & $\mathrm{mg} \mathrm{kg}^{-1} \mathrm{DM}$ & $3.29 \pm 0.54$ & $4.42 \pm 0.94$ \\
\hline $\mathrm{Zn}_{\text {total }}$ & $\mathrm{mg} \mathrm{kg}^{-1} \mathrm{DM}$ & $243 \pm 11.0$ & $358 \pm 77.0$ \\
\hline Specific surface area $\left(\mathrm{S}_{\mathrm{BET}}\right)$ & $\mathrm{m}^{2} \mathrm{~g}^{-1}$ & $1.83 \pm 0.22$ & $2.76 \pm 0.29$ \\
\hline Pore volume & $\mathrm{cm}^{3} \mathrm{~g}^{-1}$ & $0.006 \pm<0.01$ & $0.011 \pm<0.01$ \\
\hline Pore diameter & $\mathrm{nm}$ & $14 \pm 2$ & $18 \pm 3$ \\
\hline
\end{tabular}

Each value represents the mean of three replicates \pm standard deviation a stainless steel sampler. For chemical analyses, soil samples were air dried at the room temperature and $1 \mathrm{~mm}$ sieved. Samples for biological analyses were thoroughly mixed, $2 \mathrm{~mm}$ sieved, and stored at $5 \pm 2{ }^{\circ} \mathrm{C}$. Soil samples were analysed within 3 days after sampling. All biological determinations were performed in fresh soil samples. The study presents the results of the second year of the experiment (18 months after the application of organic materials).

\section{Meteorological Conditions During the Micro-Plot Experiment in 2015}

The weather conditions (precipitation, temperature) during the experiment are shown in Fig. 1. The highest precipitation $(103.9 \mathrm{~mm}$ ) was observed in May, and the lowest $(7.1 \mathrm{~mm})$ in December. The highest monthly mean air temperature $\left(17-21^{\circ} \mathrm{C}\right)$ was recorded from June to September.
Fig. 1 Monthly sums of precipitation $(\mathrm{mm})$ and monthly mean air temperature $\left({ }^{\circ} \mathrm{C}\right)$

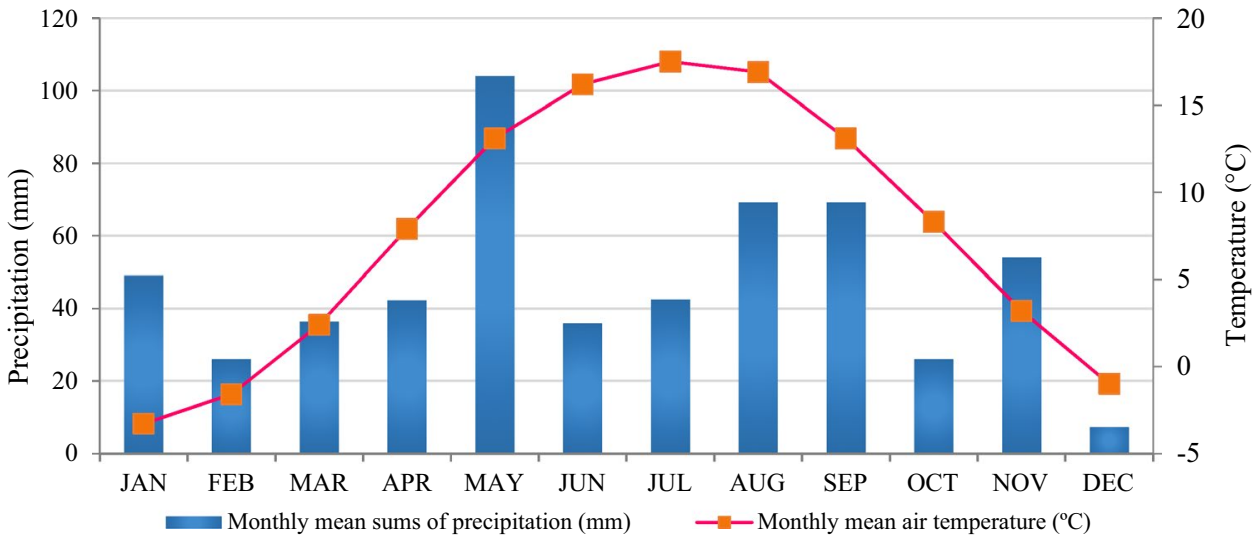




\section{Determinations of Soil Properties}

The following parameters were determined in soil samples dried at room temperature and $1 \mathrm{~mm}$ sieved: $\mathrm{pH}$ - by potentiometric method-in the suspensions of soil and water, and soil and $1 \mathrm{~mol} \mathrm{dm}^{-3}$ solution of $\mathrm{KCl}$ (soil:solution=1:2.5); electrical conductivity (EC) - by conductometric method $[16,26]$. The contents of total nitrogen and sulphur were determined on the CNS analyser (Vario MAX Cube, Elementar) [15]. The soil organic carbon content was determined by the Tiurin's method. The total contents of selected trace elements were determined after incineration of soil organic matter in a chamber furnace (at $450{ }^{\circ} \mathrm{C}$ for $8 \mathrm{~h}$ ) and mineralisation of the residue in a mixture of concentrated nitric and perchloric acids (3:2) (v/v) [33]. The contents of the studied elements in the obtained solutions were determined by the ICP-OES method using the Perkin Elmer Optima 7300 DV instrument [42].

\section{Determination of the Microbial Parameters}

The basal respiration (BR) was determined according to ISO 16072 [25] method. Field-moist soil subsamples of $20 \mathrm{~g}$ (moisture of $60 \%$ ) were placed in $900 \mathrm{~cm}^{3}$ gas-tight jars and incubated at $20 \pm 2{ }^{\circ} \mathrm{C}$ for $24 \mathrm{~h}$. The released $\mathrm{CO}_{2}$ was absorbed in $0.05 \mathrm{M}$ solution of $\mathrm{NaOH}$ and precipitated as barium carbonate by adding $0.5 \mathrm{M}$ solution of $\mathrm{BaCl}_{2}$. The non-consumed sodium hydroxide was titrated with $0.1 \mathrm{M} \mathrm{HCl}$ in the presence of phenolphthalein as indicator, and then the amount of $\mathrm{CO}_{2}$ was calculated [25].

\section{Microbial Biomass}

The microbial biomass $\left(\mathrm{C}_{\text {mic }}\right)$ in soil samples was measured by the substrate-induced respiration method-SIR [27]. SIR was determined by the quantification of the carbon dioxide evolution shortly (6 h) after addition of glucose (aqueous solution equivalent to $10 \mathrm{~g}$ glucose per $\mathrm{kg}$ of soil). $\mathrm{C}_{\text {mic }}$ was calculated from the substrate-induced respiration rate using the following equation [27]:

$C_{\text {mic }}\left(\mu g g^{-1}\right)=40.4 \cdot R+0.37$

where $\mathrm{R}$ is given in $\mathrm{mm}^{3} \mathrm{CO}_{2} \mathrm{~g}^{-1} \mathrm{~h}^{-1}$.

Respiratory-Activation Quotient and Microbial Coefficient Finally, respiratory-activation quotient $(\mathrm{QR})$ and microbial coefficient $\left(\mathrm{C}_{\mathrm{mic}} / \mathrm{C}_{\text {org }}\right)$ were calculated. $\mathrm{QR}$ was calculated by dividing the BR rate by the SIR rate according to ISO 17155 [29]. Microbial coefficient was calculated as a ratio between microbial biomass $\left(\mathrm{C}_{\text {mic }}\right)$ and soil organic carbon $\left(\mathrm{C}_{\text {org }}\right)$, as proposed by Insam and Domsch [23].
Nitrifying Bacteria Activity in Soils For determination of nitrification potential in soil samples, ISO 15685 method [28] was applied with some modifications. The detailed description of this procedure was given in Maliszewska-Kordybach et al. [38]. Field-moist soil subsamples of $25 \mathrm{~g}$ (moisture of $60 \%$ ) were mixed with a mineral medium to form slurry. The mineral medium contained $1.5 \mathrm{mmol} \mathrm{dm}^{-3}$ of $\left(\mathrm{NH}_{4}\right)_{2} \mathrm{SO}_{4}$ as a substrate, $1 \mathrm{mmol} \mathrm{dm}^{-3}$ of potassium phosphate buffer $\left(\mathrm{KH}_{2} \mathrm{PO}_{4}\right.$ and $\left.\mathrm{K}_{2} \mathrm{HPO}_{4}\right)$ and $5.625 \mathrm{mmol} \mathrm{dm}^{-3}$ of $\mathrm{NaClO}_{3}$ (to prevent further oxidation of $\mathrm{NO}_{2}^{-}$to $\mathrm{NO}_{3}^{-}$). Soil slurries were mixed for $24 \mathrm{~h}$ on a shaker at approx. $125 \mathrm{rpm}$ and at $25 \pm 2{ }^{\circ} \mathrm{C}$. After incubation, $5 \mathrm{~cm}^{3}$ of $4 \mathrm{~mol} \mathrm{dm}^{-3} \mathrm{KCl}$ were added to the slurry, and the suspension was filtered using 390-grade filter paper. Then, the filtrate was transferred to a glass flask filled with deionised water and the colour reagent containing sulphanilamide and $\mathrm{N}$-(1-naphtyl)ethylene diamine dihydrochloride. After $60 \mathrm{~min}$, the amount of $\mathrm{NO}_{2}$-formed in the nitrification process was determined spectrophotometrically (Lambda 45 UV-VIS spectrophotometer, Perkin Elmer, the USA) at $\lambda=543 \mathrm{~nm}$, and expressed as $\mu \mathrm{g} \mathrm{NO}_{2}^{-} \cdot \mathrm{g}^{-1}$ of soil.

All microbial parameter determinations were done in triplicates for each of the replicate soil samples, and the final results were given as an arithmetic mean of nine measurements. Each series of measurements included control samples without soil material. The results of this study were compared to the MF treatment to show the real impact of organic materials (poultry litter and poultry litter biochar) on microbial parameters of analysed treatments.

Statistical Analysis Mean values were taken from each triplicate data set. The differences between each object and the control as well as between objects were evaluated using a one-way analysis of variance (ANOVA) followed by Duncan's post hoc test. All statistical analyses were performed using Statistica PL 12.5 software with a level of confidence of $p \leq 0.05$. Variation within objects was determined by calculating the values of standard deviation $( \pm \mathrm{SD})$.

\section{Results and Discussion}

\section{Soil Properties Before and After 2 Years of Experiment}

When assessing the stability of biochar and its influence on soil, it is important to know the physical and chemical properties of biochar, which, in turn, have a direct impact on the biological properties of soil. Literature data show that due to the complex, specific, and resistant-to-microbial-decomposition structure (presence of condensed aromatic structures), biochar is a "difficult" source of nutrients for soil microorganisms [36]. Kuzyakov et al. [34] estimated that the rate of biochar decomposition in soil is very 
low and ranges from 0.0013 to $0.05 \%$ per day. However, despite its structure, biochar may create suitable conditions for the growth and development of soil microorganisms, as it improves the physical and chemical properties of soil [3, $31,34,40]$.

The soil on which the experiment was set up had a slightly alkaline reaction $\left(\mathrm{pHH}_{2} \mathrm{O}=6.46\right)$ and natural contents of heavy metals (Table 2). The content of total nitrogen in soil before setting up the experiment was $1.28 \mathrm{~g} \mathrm{~kg}^{-1} \mathrm{DM}$, and the content of total organic carbon was $9.80 \mathrm{~g} \mathrm{~kg}^{-1} \mathrm{DM}$.

The application of organic materials to the soil resulted in no statistically significant changes in the soil $\mathrm{pH}$ values in comparison to the value determined in MF treatment (Table 3). Moreover, in objects with organic materials, the

Table 2 Selected soil properties $(0-10 \mathrm{~cm})$ before setting up the field experiment

\begin{tabular}{lll}
\hline Determination & Unit & Value \\
\hline Sand & $\%$ & 73 \\
Silt & $\%$ & 15 \\
Clay & $\%$ & 12 \\
$\mathrm{pH} \mathrm{H} \mathrm{H}_{2} \mathrm{O}$ & - & $6.46 \pm 0.02$ \\
$\mathrm{pH} \mathrm{KCl}$ & - & $5.59 \pm 0.01$ \\
Electrical conductivity $(\mathrm{EC})$ & $\mu \mathrm{S} \mathrm{cm}^{-1}$ & $22.0 \pm 0.00$ \\
Organic carbon $\left(\mathrm{C}_{\text {org }}\right)$ & $\mathrm{g} \mathrm{kg}^{-1} \mathrm{DM}$ & $9.80 \pm 0.05$ \\
$\mathrm{~N}_{\text {total }}$ & $\mathrm{g} \mathrm{kg}^{-1} \mathrm{DM}$ & $1.28 \pm 0.02$ \\
$\mathrm{~S}_{\text {total }}$ & $\mathrm{g} \mathrm{kg}^{-1} \mathrm{DM}$ & $0.17 \pm 0.00$ \\
$\mathrm{P}_{\text {total }}$ & $\mathrm{g} \mathrm{kg}^{-1} \mathrm{DM}$ & $1.13 \pm 0.14$ \\
$\mathrm{~K}_{\text {total }}$ & $\mathrm{g} \mathrm{kg}^{-1} \mathrm{DM}$ & $1.23 \pm 0.01$ \\
$\mathrm{C}: \mathrm{N} \mathrm{ratio}$ & - & 7.66 \\
$\mathrm{Cd}_{\text {total }}$ & $\mathrm{mg} \mathrm{kg}^{-1} \mathrm{DM}$ & $0.63 \pm 0.01$ \\
$\mathrm{Cr}_{\text {total }}$ & $\mathrm{mg} \mathrm{kg}^{-1} \mathrm{DM}$ & $7.05 \pm 1.37$ \\
$\mathrm{Cu}_{\text {total }}$ & $\mathrm{mg} \mathrm{kg}^{-1} \mathrm{DM}$ & $5.84 \pm 0.42$ \\
$\mathrm{~Pb}_{\text {total }}$ & $\mathrm{mg} \mathrm{kg}^{-1} \mathrm{DM}$ & $25.5 \pm 0.65$ \\
$\mathrm{Ni}_{\text {total }}$ & $\mathrm{mg} \mathrm{kg}^{-1} \mathrm{DM}$ & $4.20 \pm 0.82$ \\
$\mathrm{Zn}_{\text {total }}$ & $\mathrm{mg} \mathrm{kg}^{-1} \mathrm{DM}$ & $138.5 \pm 5.33$ \\
\hline $\mathrm{Z}$ &
\end{tabular}

Each value represents the mean of three replicates \pm standard deviation electrical conductivity value was considerably higher (by $138 \%$ on average compared to EC determined in soil before the experiment). It is likely that the increased amount of ions (as measured by EC) available in the soil due to the presence of biochar benefited the plants with increased uptake of nutrients, increased microbial activity, and better water retention. Unfortunately, the EC soil property interactions are not easily identified, since the magnitude of the reactions regulating soil EC levels is complex and dynamic. Thus, it is important to investigate the changes on EC in soils treated with different organic materials, because EC reflects the sum of salts and ions in the soil solution, the levels of which are regulated by the type, composition and amount of organic materials added to the soil [18, 35, 37].

This study's findings indicated that organic materials applied to the soil caused no significant increase in the contents of nitrogen and carbon, which are key nutrients for soil microorganisms (Table 3). The lowest $\mathrm{C}$ and $\mathrm{N}$ contents were determined in the control soil (C) and the highest in the soil fertilised with poultry litter (PL). However, these differences were not statistically significant, which probably resulted from a relatively low dose of the material.

The lowest value of the analysed $\mathrm{C}: \mathrm{N}$ ratio was found in soil with the addition of $5 \mathrm{t} \mathrm{DM} \mathrm{ha}{ }^{-1}$ of poultry litter biochar (PLB II) - and the highest-in soil with poultry litter (PL) applied in the same amount. Ameloot et al. [3] also indicated the relevance of the $\mathrm{C}: \mathrm{N}$ ratio value and changes in the soil $\mathrm{pH}$ after the application of biochar. The above authors emphasised that these parameters play an essential role in stimulating and reducing the activity of microorganisms responsible for the mineralisation of soil organic matter. Also Schomberg et al. [45] and Jones et al. [31] demonstrated a strong positive correlation between the increase in $\mathrm{C}: \mathrm{N}$ value in soil and microbial biomass.

\section{Effects of Poultry Litter Biochar on Soil Microbial Biomass}

The effect of organic materials introduced into the soil on biological properties has repeatedly been a matter of debate between scientists [36]. However, the results of studies on
Table 3 Selected soil properties (layer $0-10 \mathrm{~cm}$ ) after 18 months of field experiment

\begin{tabular}{lllllll}
\hline Determination & Unit & $\mathrm{C}$ & $\mathrm{MF}$ & PL & PLB I & PLB II \\
\hline $\mathrm{pH} \mathrm{H} \mathrm{H}_{2} \mathrm{O}$ & - & $6.75 \mathrm{a}^{*} \pm 0.52$ & $6.56 \mathrm{a} \pm 0.27$ & $6.60 \mathrm{a} \pm 0.26$ & $6.49 \mathrm{a} \pm 0.12$ & $6.57 \mathrm{a} \pm 0.18$ \\
$\mathrm{pH} \mathrm{KCl}$ & - & $5.70 \mathrm{a} \pm 0.31$ & $5.34 \mathrm{a} \pm 0.10$ & $5.49 \mathrm{a} \pm 0.34$ & $5.59 \mathrm{a} \pm 0.26$ & $5.46 \mathrm{a} \pm 0.09$ \\
Electrical conductivity & $\mu \mathrm{S} \mathrm{cm}^{-1}$ & $40.7 \mathrm{a} \pm 0.00$ & $45.0 \mathrm{a} \pm 0.00$ & $46.6 \mathrm{a} \pm 0.01$ & $37.4 \mathrm{a} \pm 0.01$ & $48.8 \mathrm{~b} \pm 0.00$ \\
$\mathrm{SOC}$ & $\mathrm{g} \mathrm{kg}^{-1} \mathrm{DM}$ & $10.3 \mathrm{a} \pm 0.75$ & $10.4 \mathrm{a} \pm 2.04$ & $11.8 \mathrm{a} \pm 1.57$ & $11.0 \mathrm{a} \pm 1.00$ & $10.4 \mathrm{a} \pm 0.86$ \\
$\mathrm{~N}_{\text {total }}$ & $\mathrm{g} \mathrm{kg}^{-1} \mathrm{DM}$ & $0.94 \mathrm{a} \pm 0.01$ & $0.96 \mathrm{a} \pm 0.04$ & $0.98 \mathrm{a} \pm 0.06$ & $0.94 \mathrm{a} \pm 0.05$ & $0.97 \mathrm{a} \pm 0.06$ \\
$\mathrm{C}: \mathrm{N}$ ratio & - & 11.0 & 10.8 & 12.0 & 11.7 & 10.6 \\
\hline
\end{tabular}

Each value represents the mean of three replicates \pm standard deviation; *mean values marked with the different letters differ significantly according to the Duncan's test at $\mathrm{p} \leq 0.05$; factor: fertilisation 
the microbial response to the presence of biochar in the soil are often ambiguous and inconsistent. Bruun et al. [7] and Luo et al. [37] proved that thermally unconverted poultry litter and poultry litter biochar added to the soil causes an increase in microbial biomass. The authors believed that this results from the introduction into the soil of labile carbon compounds with these materials. In our study, the highest, statistically significant microbial biomass values were determined in the soil with the addition of poultry litter $\left(53.6 \mu \mathrm{g} \mathrm{g}^{-1} \mathrm{DM}\right.$ soil), and the lowest, in the MF treatment (27.2 $\mu \mathrm{g} \mathrm{g}^{-1} \mathrm{DM}$ soil) (Fig. 2). In objects with poultry litter biochar added in $2.25 \mathrm{t}$ and $5 \mathrm{t} \mathrm{DM} \mathrm{ha}{ }^{-1}$ doses, $\mathrm{C}_{\text {mic }}$ was significantly higher than in the MF object, by 59 and $77 \%$, respectively.

Our results are partially confirmed by the observations of Ameloot et al. [3], who stated that biochar produced from poultry litter at $400{ }^{\circ} \mathrm{C}$ and applied into the soil caused no significant increase in $\mathrm{C}_{\text {mic }}$ as compared to the control soil. The above authors also demonstrated that the introduction into the soil of biochar obtained from poultry litter at higher temperature $\left(500^{\circ} \mathrm{C}\right)$ reduced microbial biomass by more than $30 \%$ in comparison with the control soil.

The opposing view on the effect of poultry litter biochar on soil microbial biomass was expressed by Castaldi et al. [8] and Zavalloni et al. [54]. These authors noted that the application of poultry litter biochar to the soil had no effect on microbial biomass, since the exogenous organic matter such as biochar is resistant to microbial decomposition. Dempster et al. [13] suggested that the reduction of microbial biomass after the application of biochar to the soil may result from the toxicity of the material. On the other hand, Cross and Sohi [11] and Ameloot et al. [3] informed that biochar is not inert when added to the soil and undergoes a biphasic mineralisation in it. The first phase includes a relatively fast mineralisation of labile carbon compounds present in biochar, which may, in a short time, intensify biological parameters of soil. The next phase of biochar decomposition has a much slower rate, and its effects may be difficult to assess due to their distribution in time.

As stated by Hofman et al. [21] and Chodak and Niklińska [12], when assessing the environmental effect, a much better parameter than microbial biomass is a ratio between carbon concentration in microbial biomass $\left(\mathrm{C}_{\text {mic }}\right)$ and the content of total soil organic carbon $\left(\mathrm{C}_{\text {org }}\right)$. The ratio may be interpreted as the availability of substrates for soil microorganisms. The resulting coefficients $\mathrm{C}_{\text {mic }} / \mathrm{C}_{\text {org }}$ showed no significant differences between objects (Fig. 2). The highest availability of nutrients for microorganisms was observed in the soil with the addition of poultry litter (PL) and in the soil with $5 \mathrm{t} \mathrm{DM} \mathrm{ha}^{-1}$ dose of poultry litter biochar (PLB II). These objects were also noted for the highest values of microbial biomass.

\section{Effects of Poultry Litter Biochar on Microbial Soil Respiration}

The metabolic activity of microorganisms referred to as 'soil respiration' is a parameter which depends on the physiological condition of soil microorganisms and environmental factors. Despite the high variability of soil conditions, such as: humidity, soil $\mathrm{pH}$, temperature, nutrient availability, or soil structure, it is believed that soil respiration activity constitutes a very sensitive parameter, closely connected to other biological properties of soil [19]. Basal respiration (BR) determined in our study showed low variability in the analysed soils (Fig. 3). Further, significant differences in the parameter values were observed in soils with distinct changes in microbial biomass (Fig. 2). Compared to the MF soil, the highest and statistically significant increase of the BR value (by 50\%) was determined in the soil with $5 \mathrm{t} \mathrm{DM} \mathrm{ha}^{-1}$ dose of biochar (PLB II). This suggests that decomposition of organic matter was the most intensive in the object with PLB II. On the other hand, basal respiration in the soil amended with poultry litter and lower dose of poultry litter biochar $\left(2.25 \mathrm{t} \mathrm{DM} \mathrm{ha}^{-1}\right)$ caused no significant increase of $\mathrm{BR}$ values in comparison to the MF treatment. The highest reduction of the BR parameter (by $19 \%$ in relation to the control soil (C)) was reported in the MF treatment (Fig. 3). According to Spohn [47], reduced respiration activity of soil microorganisms may result from not only lower amount of biomass, but also reduced value of $\mathrm{C}: \mathrm{N}$ ratio in soil.
Fig. 2 Effect of PL biochar on microbial biomass $\left(\mathrm{C}_{\mathrm{mic}}\right)$ and microbial coefficient $\left(\mathrm{C}_{\text {mic }} / \mathrm{C}_{\text {org }}\right.$ ratio). Each value represents the mean of nine replicates \pm standard deviation *mean values marked with the different letters differ significantly according to the Duncan's test at $\mathrm{p} \leq 0.05$; factor: fertilisation
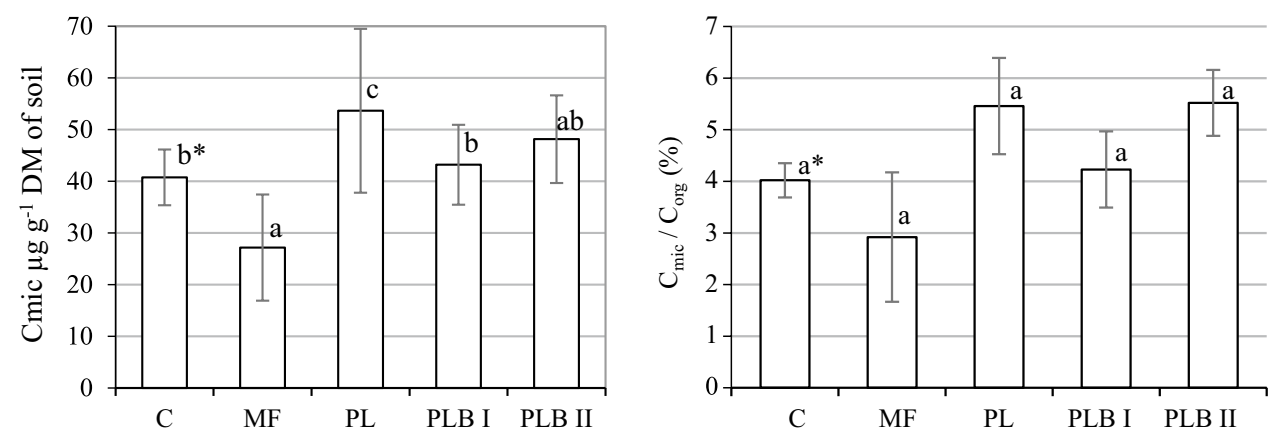
Fig. 3 BR-Basal respiration, SIR - substrate induced respiration, QR-respiratory activation quotient of control and amended soils. Each value represents the mean of nine replicates \pm standard deviation *mean values marked with the different letters differ significantly according to the Duncan's test at $\mathrm{p} \leq 0.05$; factor: fertilisation
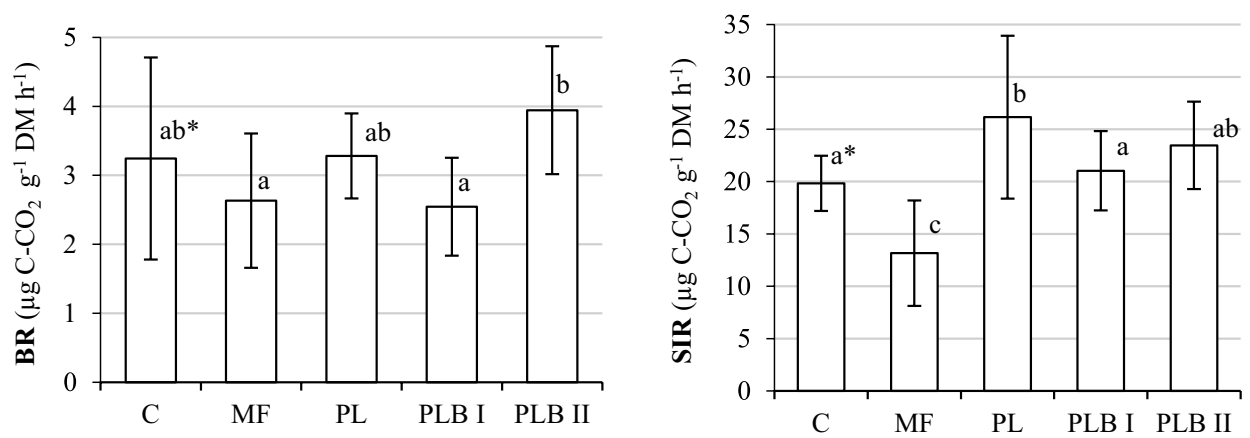

The addition of a substrate (glucose) to the analysed soil samples caused a considerable increase (even up to 8 times) in the respiration rate (Fig. 3). This is due to the introduction of a source of easily accessible carbon into the microorganism habitat. Additionally, it can be concluded that there were no inhibitory substances in these soil samples or they were present in concentrations which had no inhibiting effect on the life processes of dormant soil microorganisms. The greatest increase of the SIR parameter was determined in objects with PL and PLB II (Fig. 3), characterised by the highest activity of biomass of heterotrophic aerobic microorganisms (Fig. 2). The lowest microbial respiration activity was reported in the MF treatment, in which basal and induced respiration values were reduced by 19 and 33\%, respectively. Many authors confirmed the beneficial effect of biochar produced at temperatures from 250 to $400{ }^{\circ} \mathrm{C}$ on soil respiration activity [11, 31, 51]. In turn, Zimmerman et al. [55] and Dempster et al. [13] demonstrated a reduction of the parameter value after applying biochar produced at $>525^{\circ} \mathrm{C}$. According to these authors, the reason for this phenomenon lies in the toxic effect of biochar and adsorption of the labile organic matter fraction by this material.

The respiratory-activation quotient $(\mathrm{QR})$ calculated in our study, which represents the number of dormant or active microorganisms, ranged from 0.13 to 0.25 . As stated by Eisentraeger et al. [14], the value of respiratory-activation quotient between 0.1 and 0.3 is low and indicates a large amount of biomass of inactive microorganisms. In addition, the value may suggest low bioremediation rate in the presence of any toxic substances in soil. Given the microbial biomass criterion, it is believed that high value of basal respiration (BR) is the most desirable for soil. Taking into account observations of the above authors, the lowest values of microbiological parameters (BR, SIR) were noted for MF treatment (Fig. 3). In our study, the highest and statistically significant QR values, compared to the object with MF, were determined in the soil with poultry litter (PL) and in the soil with $2.25 \mathrm{t} \mathrm{DM} \mathrm{ha}^{-1}$ dose of poultry litter biochar (PLB I) (Fig. 3). On the other hand, [36] and Ameloot et al. [2] concluded that the beneficial effect of biochar on the increase of population and activity of soil microorganisms should be attributed not only to the supply of nutrients, but also retention of water (which is a medium for nutrient transportation) in biochar pores.

\section{Effect of PL Biochar on Soil Nitrifying Bacteria Activity}

Another very sensitive parameter which reflects the response of soil microorganisms to environmental changes is the soil nitrification potential (NIT) [36, 44]. The nitrification potential enables determination of the potential activity of a specialised group of autotrophic bacteriaammonia-oxidising bacteria dominated by two genera Nitrosomonas and Nitrosospira-responsible for the first phase of nitrification. The second phase of nitrification (oxidation of $\mathrm{NO}_{2}^{-}$to $\mathrm{NO}_{3}^{-}$) is possible mainly due to bacteria of Nitrobacter genus [5, 52]. The nitrification process is of great importance in maintaining the balance between various nitrogen forms, acting as a link between ammonification and denitrification. According to Wang et al. [52], the soil $\mathrm{pH}$ value, the number of ions $\mathrm{NH}_{4}^{+}$, soil 
temperature, and the organic matter content have a critical impact on the number of nitrifying bacteria. The addition of biochar into the soil may also reduce the emission of $\mathrm{N}_{2} \mathrm{O}$ from soil [9], have no effect on it [49], or increase the emission of $\mathrm{N}_{2} \mathrm{O}$ from soil [44].

Our study proved that the addition of poultry litter had significant effect on nitrifying bacteria activity. Compared to the MF treatment, nitrifying bacteria activity in the soil of that object was higher by $43 \%$ (Fig. 4). Significant positive effect of the addition of thermally unconverted poultry litter (PL) is probably the result of ammonia nitrogen load present in the material and content of DOC (Table 1). In the case of thermally converted poultry litter (PLB I and PLB II), we observed no significant effect on the NIT parameter values compared to the soil with MF. Nevertheless, the application of poultry litter biochar in doses of $2.25 \mathrm{t}$ and $5 \mathrm{t} \mathrm{DM} \mathrm{ha}^{-1}$ contributed to an increase in nitrifying bacteria activity by 36 and $34 \%$, respectively compared to the object with MF. Given the fact that the analysed soil samples had comparable physical and chemical properties (Table 3), it is possible that the observed activity was related to the number of nitrifying bacteria in the organic materials. On the other hand, observations of Wang et al. [52] suggested that 3 and 5\% additions of biochar to the soil affected and inhibited the nitrification process.

The results of our study indicate that the lowest nitrification potential was observed in the MF treatment in which nitrifying bacteria activity was reduced by $26 \%$ compared to the control soil (Fig. 4). This may reflect the availability of less favourable conditions for the development of nitrifying bacteria, as confirmed by Clough et al. [10] and Wang et al. [52]. Study conducted by these authors proved that the application of biochar to soil may inhibit the activity of soil microorganisms due to the presence of phenolic compounds (PHCs) and polycyclic aromatic hydrocarbons

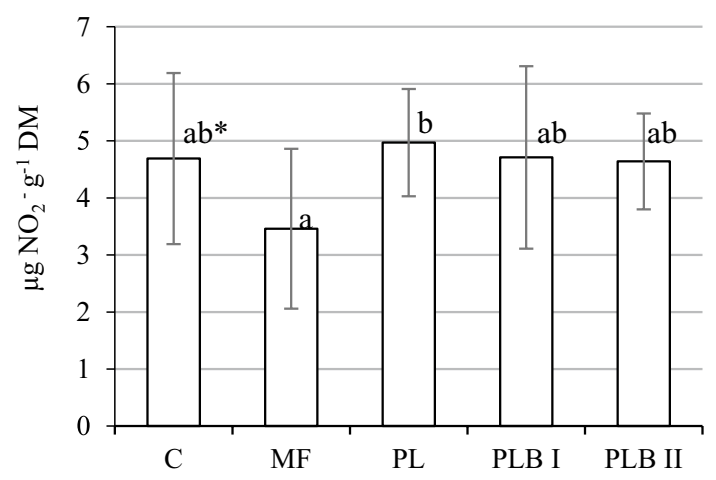

Fig. 4 Influence of PL biochar on nitrification potential. Each value represents the mean of nine replicates \pm standard deviation *mean values marked with the different letters differ significantly according to the Duncan's test at $p \leq 0.05$; factor: fertilisation
(PAH) in the material, which were formed during its production.

Weather conditions, and in particular the amount and distribution of precipitation could be an important factor with a direct effect on the biological activity of the soil in the study. Precipitation influences the formation of air and water conditions in the soil and the availability of nutrients for microorganisms, as well as the intensity of their biochemical reactions. A large variation in precipitation was observed between individual months of the second year of the experiment (Fig. 1). The second year of the experiment was characterised by lower precipitation and lower temperature values compared to the values recorded for the year in which the experiment was set up [40].

\section{Conclusions}

In objects with biochar added in $2.25 \mathrm{t}$ and $5 \mathrm{t} \mathrm{DM} \mathrm{ha}$ doses, microbial biomass $\left(\mathrm{C}_{\text {mic }}\right)$ was significantly higher than in the MF treatment, by 59 and $77 \%$, respectively. The significantly highest basal respiration value was determined in soil with $5 \mathrm{t} \mathrm{DM} \mathrm{ha}{ }^{-1}$ biochar. Basal respiration in the soil amended with poultry litter and lower dose of poultry litter biochar $\left(2.25 \mathrm{t} \mathrm{DM} \mathrm{ha}{ }^{-1}\right)$ caused no significant increase of BR values in comparison to the soil with mineral fertilisation (MF). The application of poultry litter had significant effect on nitrifying bacteria activity (increase by $50 \%$ ). Nevertheless, the application of poultry litter biochar in doses of $2.25 \mathrm{t}$ and $5 \mathrm{t} \mathrm{DM} \mathrm{ha}^{-1}$ contributed to an increase in nitrifying bacteria activity by 36 and 34\%, respectively compared to MF treatment. Basal respiration, microbial biomass and nitrifying bacteria activity are sensitive tools for rapid verification of the effects of changes in the environment and monitoring of soil quality.

Acknowledgements The Research was financed by the Ministry of Science and Higher Education of the Republic of Poland.

Open Access This article is distributed under the terms of the Creative Commons Attribution 4.0 International License (http:// creativecommons.org/licenses/by/4.0/), which permits unrestricted use, distribution, and reproduction in any medium, provided you give appropriate credit to the original author(s) and the source, provide a link to the Creative Commons license, and indicate if changes were made.

\section{References}

1. Al-Wabel, M.I., Al-Omran, A., El-Naggar, A.H., Nadeem, M., Usman, A.R.A.: (2013) Pyrolysis temperature induced changes in characteristics and chemical composition of biochar produced from conocarpus wastes. Biores. Technol. 131, 374-379 (2013). doi:10.1016/j.biortech.2012.12.165 
2. Ameloot, N., De Neve, S., Jegajeevagan, K., Yildiz, G., Buchan, D., Funkuin, Y.N., Prins, W., Bouckaert, L., Sleutel, S.: Shortterm $\mathrm{CO}_{2}$ and $\mathrm{N}_{2} \mathrm{O}$ emissions and microbial properties of biochar amended sandy loam soils. Soil Biol. Biochem. 57, 401-410 (2013). doi:10.1016/j.soilbio.2012.10.025

3. Ameloot, N., Sleutel, S., Das, K.C., Kanagaratnam, J.J., de Neve, S.: Biochar amendment to soils with contrasting organic matter level: effects on $\mathrm{N}$ mineralization and biological soil properties. Bioenergy 7, 135-144 (2015). doi:10.1111/gcbb.12119

4. Anderson, C.R., Condron, L.M., Clough, T.J., Fiers, M., Stewart, A., Hill, R.A., Sherlock, R.R.: Biochar induced soil microbial community change: implications for biogeochemical cycling of carbon, nitrogen and phosphorus. Pedobiology 54, 309-320 (2011). doi:10.1016/j.pedobi.2011.07.005

5. Ball, P.N., MacKenzie, M.D., DeLuca, T.H., Montana, W.E.H.: Wildfire and charcoal enhance nitrification and ammonium-oxidizing bacterial abundance in dry montane forest soils. J. Environ. Qual. 39, 1243-1253 (2010). doi:10.2134/jeq2009.0082

6. Barret, E.P., Joyner, L.G., Halenda, P.H.: The determination of pore volume and area distributions in porous substances. I. Computations from nitrogen isotherms. J. Amer. Chem. Soc. 73(1), 373-380 (1951). doi:10.1021/ja01145a126

7. Bruun, E.W., Hauggaard-Nielsen, H., Ibrahim, N., Egsgaard, H., Ambus, P., Jensen, P.A., DamJohansen, K.: Influence of fast pyrolysis temperature on biochar labile fraction and short-term carbon loss in a loamy soil. Biomass Bioenergy 35, 1182-1189 (2011). doi:10.1016/j.biombioe.2010.12.008

8. Castaldi, S., Riondino, M., Baronti, S., Esposito Marzaioli, R., Rutigliano, F.A., Vaccari, F.P., Miglietta, F.: Impact of biochar application to a Mediterranean wheat crop on soil microbial activity and greenhouse gas fluxes. Chemosphere 85, 1464-1471 (2011). doi:10.1016/j.chemosphere.2011.08

9. Cayuela, M.L., Van Zwieten, L., Singh, B.P., Jeffery, S., Roig, A., Sánchez Monedero, M.A.: Biochar's role in mitigating soil nitrous oxideemissions: a review and meta-analysis. Agric. Ecosyst. Environ. 191, 5-16 (2014). doi:10.1016/j.agee.2013.10.009

10. Clough, T.J., Bertram, J.E., Ray, J.L., Condron, L.M., O'Callaghan, M., Sherlock, R.R., Wells, N.S.: Unweathered wood biochar impact on nitrous oxideemissions from a bovineurine-amended pasture soil. Soil Sci. Soc. Am. J. 74, 852-860 (2010). doi:10.2136/sssaj2009.0185

11. Cross, A., Sohi, S.P.: The priming potential of biochar products in relation to labile carbon contents and soil organic matter status. Soil Biol. Biochem. 43, 2127-2134 (2011). doi:10.1016/j. soilbio.2011.06.016

12. Chodak, M., Niklińska, M.: Development of microbial biomass and enzyme activities in mine Soils. Pol. J. Environ. Stud. 21(3), 569-577 (2012). http://www.eko.uj.edu.pl/ecotox/PDF/ PJES2012_Chodak.pdf

13. Dempster, D.N., Gleeson, D.B., Solaiman, Z.M., Jones, D.L., Murphy, D.V.: Decreased soil microbial biomass and nitrogen mineralisation with Eucalyptus biochar addition to a coarse textured soil. Plant Soil 354, 311-324 (2012). doi:10.1007/ s11104-011-1067-5

14. Eisentraeger, A., Maxam, G., Rila, J.-P., Dott, W.: A stepwise procedure for assessment of the microbial respiratory activity of soil samples contaminated with organic compounds. Ecotoxicol. Environ. Saf. 47, 65-73 (2000). doi:10.1006/eesa.2000.1933

15. Elementar Analysensysteme $\mathrm{GmbH}$ : Operating instructions vario MAX cube pp. 407 (2013)

16. Głąb, T., Gondek, K.: The influence of soil compaction and $\mathrm{N}$ fertilization on physico-chemical properties of mollic fluvisoil soil under red clover/grass mixture. Geoderma. 226-227, 204212 (2014). doi:10.1016/j.geoderma.2014.02.021

17. Gondek, K., Baran, A., Kopeć, M.: The effect of low-temperature tran)sformation of mixtures of sewage sludge and plant materiale on content, leachability and toxicity of heavy metals. Chemosphere 117, 33-39 (2014). doi:10.1016/j. chemosphere.2014.05.032

18. Gondek, K., Mierzwa-Hersztek, M.: Effect of low-temperature biochar derived from pig manure and poultry litter on mobile and organic matter-bound forms of $\mathrm{Cu}, \mathrm{Cd}, \mathrm{Pb}$ and $\mathrm{Zn}$ in sandy soil. Soil Use Manag. 32, 357-367 (2016). doi:10.1111/sum.12285

19. Han, G., Zhou, G., Xu, Z., Yang, Y., Liu, J., Shi, K.: Soil temperature and biotic factors drive the seasonal variation of soil respiration in a maize (Zea mays L.) agricultural ecosystem. Plant Soil 291, 15-26 (2007). doi:10.1007/s11104-006-9170-8

20. Hilscher, A., Heister, K., Siewert, C., Knicker, H.: Mineralisation and structural changes during the initial phase of microbial degradation of pyrogenic plant residues in soil. Org. Geochem. 40, 332-342 (2009). doi:10.1016/j.orggeochem.2008.12.004

21. Hofman, J., Dušek, L., Klánová, J., Bezchlebová, J., Holoubek, I.: Monitoring microbial biomass and respiration in different soils from the Czech Republic - a summary of results. Environ. Int. 30, 19-30 (2004). doi:10.1016/S0160-4120(03)00142-9

22. IBI: Standardized product definition and product testing guidelines for biochar that is used in soil (2012). http://www.biocharinternational.org/characterizationstandard

23. Insam, H., Domsch, K.H.: Relationship between soil organic carbon and microbial biomass on consequences of reclamation sites. Microb. Ecol. 15, 177-188 (1988). doi:10.1007/BF02011711

24. Ippolito, J.A., Laird, D.A., Busscher, J.W.: Environmental Benefi ts of Biochar. J. Environ. Qual. 41, 967-972 (2012). doi:10.2134/ jeq2012.0151

25. ISO 14240-1: Soil quality-Determination of Soil Microbial Biomass-Part 1: Substrate-Induced Respiration Method. International Organisation for Standardisation, Geneva (1997)

26. ISO 16072: Soil quality—Laboratory Methods for Determination of Microbial Soil Respiration. International Organisation for Standardisation, Geneva (2002)

27. ISO 15685: Soil quality-determination of potential nitrification and inhibition of nitrification-Rapid test by ammonium oxidation. International Organisation for Standardisation, Geneva (2004)

28. ISO 17155: Soil quality-Determination of abundance and activity of soil microflora using respiration curves. International Organisation for Standardisation, Geneva (2012)

29. Jaremko, D., Kalembasa, D.: A comparison of method for the determination of cation exchange capacity of soils. Ecol. Chem. Eng. S 21(3), 487-498 (2014). doi:10.2478/eces-2014-0036

30. Jindo, K., Suto, K., Matsumoto, K., Garcia, C., Sonoki, T., Sanchez-Monedero, M.A.: Chemical and biochemical characterisation of biochar-blended composts prepared from poultry manure. Biores. Technol. 110, 396-404 (2012). doi:10.1016/j. biortech.2012.01.120.

31. Jones, D.L., Murphy, D.V., Khalid, M., Ahmad, W., EdwardsJones, G., DeLuca, T.H.: Short-term biochar-induced increase in soil $\mathrm{CO}_{2}$ release is both biotically and abiotically mediated. Soil Biol. Biochem. 43, 1723-1731 (2011). doi:10.1016/j. soilbio.2011.04.018

32. Keith, A., Singh, B., Singh, B.P.: Interactive priming of biochar and labile organic matter mineralization in a smectite-rich soil. Environ. Sci. Technol. 45, 309-313 (2011). doi:10.1021/ es $202186 \mathrm{j}$

33. Kopeć, M., Gondek, K., Baran, A.: Assessment of respiration activity and ecotoxicity of composts containing biopolymers. Ecotoxicol. Environ. Saf. 89, 137-142 (2013). doi:10.1016/j. ecoenv.2012.11.021

34. Kuzyakov, Y., Subbotina, I., Chen, H.Q., Bogomolova, I., Xu, X.L.: Black carbon decomposition and incorporation into soil microbial biomass estimated by $\mathrm{C}-14$ labeling. Soil Biol. Biochem. 41, 210-219 (2009). doi:10.1016/j.soilbio.2008.10.016 
35. Lehmann, J., Joseph, S.: Biochar for environmental management. Science, technology and implementation, 2nd edn, pp. 944 (2015)

36. Lehmann, J., Rillig, M.C., Thies, J., Masiello, C.A., Hockaday, W.C., Crowley, D.: Biochar effects on soil biota-a review. Soil Biol. Biochem. 43, 1812-1836 (2011). doi:10.1016/j. soilbio.2011.04.022

37. Luo, Y., Durenkamp, M., De Nobili, M., Lin, Q., Devonshire, B.J., Brookes, P.C.: Microbial biomass growth, following incorporation of biochars produced at $350{ }^{\circ} \mathrm{C}$ or $700{ }^{\circ} \mathrm{C}$, in a silty-clay loam soil of high and low pH. Soil Biol. Biochem. 57, 513-523 (2013). doi:10.1016/j.soilbio.2012.10.033

38. Maliszewska-Kordybach, B., Klimkowicz-Pawlas, A., Smreczak, B., Janusauskaite, D.: Ecotoxic effect of phenanthrene on nitrifying bacteria in soils of different properties. J. Environ. Qual. 36, 1635-1645 (2007). doi:10.2134/jeq2007.0118

39. Meli, S.M., Badalucco, L., English, L.C., Hopkins, D.W.: Respiratory responses of soil micro-organisms to simple and complex organic substrates. Biol. Fertil. Soils 37, 96-101 (2003). doi:10.1007/s00374-002-0570-5

40. Mierzwa-Hersztek, M., Gondek, K., Baran, A.: Effect of poultry litter biochar on soil enzymatic activity, ecotoxicity and plant growth. Appl. Soil Ecol. 105, 144-150 (2016). doi:10.1016/j. apsoil.2016.04.006

41. Mierzwa-Hersztek, M., Gondek, K.: Speciation of $\mathrm{Cd}$ and $\mathrm{Pb}$ in the soil after the biochar application. Pol. J. Agron. 24, 9-15 (2016). http://www.iung.pulawy.pl/PJA/wydane/24/PJA24doInternetustr9_15.pdf

42. Oleszczuk, N., Castro, J.T., da Silva, M.M., Korn, M.D., Welz, B., Vale, M.G.: Method development for the determination of manganese, cobalt and copper in green coffee comparing direct solid sampling electrothermal atomic absorption spectrometry and inductively coupled plasma optical emission spectrometry. Talanta 73(5), 862-869 (2007). doi:10.1016/j. talanta.2007.05.005

43. Pezzolla, D., Marconi, G., Turchetti, B., Zadra, C., Agnelli, A., Veronesi, F., Onofri, A., Benucci, G.M.N., Buzzini, P., Albertini, E., Gigliotti, G.: Influence of exogenous organic matter on prokaryotic and eukaryotic microbiota in an agricultural soil. A multidisciplinary approach. Soil Biol. Biochem. 82, 9-20 (2015). doi:10.1016/j.soilbio.2014.12.008

44. Sánchez-García, M., Roig, A., Sánchez-Monedero, M.A., Cayuela, M.L.: Biochar increases soil N2O emissions produced by nitrification-mediated pathways. Front Environ. Sci. 2(25), 1-10 (2014). doi:10.3389/fenvs.2014.00025
45. Schomberg, H.H., Wietholter, S., Griffin, T.S., Raper, R.L., Kitchen, N.R., Locke, M.A., Potter, K.N., Schwartz, R.C., Trumank, C.C., Tyler, D.D., Reeves, D.W., Cabrera, M.L., Fisher, D.S., Endale, D.M., Novak, J.M., Balkcom, K.S.: Assessing indices for predicting potential nitrogen mineralization in soils under different management systems. Soil Sci. Soc. Amer. J. 73, 15751586 (2009). doi:10.2136/sssaj2008.0303

46. Smith, J.L., Collins, H.P., Bailey, V.L.: The effect of young biochar on soil respiration. Soil Biol. Biochem. 42, 2345-2347 (2010). doi:10.1016/j.soilbio.2010.09.013

47. Spohn, M.: Microbial respiration per unit microbial biomass depends on litter layer carbon-to-nitrogen ratio. Biogeosciences 12, 817-823 (2015). doi:10.5194/bg-12-817-2015

48. Steinbeiss, S., Gleixner, G., Antonietti, M.: Effect of biochar amendment on soil carbon balance and soil microbial activity. Soil Biol. Biochem. 41, 1301-1310 (2009). doi:10.2134/ jeq2014.03.0132

49. Suddick, E.C., Six, J.: An estimation of annual nitrous oxide emissions and soil quality following the amendment of high temperature walnut shell biochar and compost to a small scale vegetable crop rotation. Sci. Total Environ. 465, 298-307 (2013). doi:10.1016/j.scitotenv.2013.01.094

50. Wagner, J.M.: Final Report: Soil Health Assessment in Organic Farming Systems. Certified Organic Associations of British Columbia, Vernon (2005)

51. Wang, Y., Hao, Y., Cui, X.Y., Zhao, H., Xu, Ch., Zhou, X., $\mathrm{Xu}, \mathrm{Z}$. : Responses of soil respiration and its components to drought stress. J Soils Sedim. 14, 99-109 (2014). doi:10.1007/ s11368-013-0799-7

52. Wang, Z., Zong, H., Zheng, H., Liu, G., Chen, L., Xing, B.: Reduced nitrification and abundance of ammonia-oxidizing bacteria in acidic soil amended with biochar. Chemosphere 138, 576-583 (2015). doi:10.1016/j.chemosphere.2015.06.084

53. WRB: World Reference Base for soIl Resources. International Soil Classification System for Naming Soils and Creating Legends for Soil Maps. Food and Agriculture Organization of the United Nations, Rome, pp 1-203. (2015)

54. Zavalloni, C., Alberti, G., Biasiol, S., Vedove, G.D., Fornasier, F., Liu, J., Peressotti, A.: Microbial mineralization of biochar and wheat straw mixture in soil: a short-term study. Appl. Soil Ecol. 50, 45-51 (2011). doi:10.1016/j.apsoil.2011.07.012

55. Zimmerman, A.R., Gao, B., Ahn, M.: Positive and negative carbon mineralization priming ffects among a variety of biocharamended soils. Soil Biol. Biochem. 43, 1169-1179 (2011). doi:10.1016/j.soilbio.2011.02.005 